\title{
The Foundations of Classic Architecture. By Herbert Langford Warren
}

\section{David M. Robinson}

To cite this article: David M. Robinson (1920) The Foundations of Classic Architecture. By Herbert Langford Warren, The Art Bulletin, 2:4, 225-227, DOI: 10.1080/00043079.1920.11409681

To link to this article: http://dx.doi.org/10.1080/00043079.1920.11409681

\section{曲 Published online: 22 Dec 2015.}

Submit your article to this journal ¿त

Q View related articles $\longleftarrow$ 


\section{REVIEWS}

The Foundations of Crassic Archtteoture. By Herbert Layaford WARREN.

Pp. Xiv, 357. Illustrated from documents and original drawings. The Macmillan Company, New York, 1919.

This handsome volume, printed on thick glossy paper, with only a few misprints (pp. 119, 143, 150, 261, 284, 327), contains five chapters, which discuss Egypt, Mesopotamia, Persia, the Aegean, and Greece (The Temple, Greek Mouldings, The Doric Order, Origin of the Doric Style, Periods of the Doric Style, The Doric Temples of the Archaic Period, The Doric Temples of the Period of Full Developement, The Ionic Style and The Ionic Order, The Culmination in Attica). The introduction, by Fiske Kimball, tells us that in this work of the former dean of the faculty of architecture of Harvard University, left in manuscript at his death, is presented in enduring form the essence of his vital teaching of the history and principles of architecture. There are quotations from W'arren's essay on the study of architectural history and an account of his life and achievements as set forth in the minute recorded by the Harvard faculty and in other tributes, and finally a brief resumé of his writings and their culmination in this book.

The book is stimulating and gives a very good general account of architecture down to the time of the Erechtheum, but unfortunately stops there and does not even take up the wonderful Hellenistic works of architecture such as the great Asia Minor temples and other buildings at Pergamum, Priene, Sardis, Ephesus, Didyma, ete., to say nothing of the Etruscan and Roman elements which belong to the foundations of classic architecture. Unfortunately, there are only 119 illustrations and many of those used, such as that of the temple at Corinth (p. 234) and those of the Erechtheum before the west wall and other walls were replaced (pp. 340, 347), have long been antiquated. It is hardly true, at least for Greek architecture, that the 
body of authentic documents here reproduced is unequalled in any general work covering the same field, (cf., for example, Sturgis, History of Architecture, vol. 1), though, to be sure there is yet no first-rate scientific history of Greek architecture in English as good as Durm's Baukunst der Griechen, and that despite the fact that American architects in the last twenty years have carried on the most important researches concerned with the buildings of the acropolis and its sides.

There are many little errors in the book which should have been read in proof or manuscript by some archaeologist with first hand knowledge. P. 136 we hear of bronze heads on the lions (rather lionesses) at the famous lions gate at Mycenae, that they and the bodies were gilt, that the relief was low. P. 137, the number of beehive tombs known is far in excess of twenty-five, and they exist from. Thessaly (rather than Boeotia) to Crete. It is not true that each beehive tomb (p. 138) has a rectangular side chamber; I know of only two such. There is no evidence that the triangular opening above the doorway of the "tomb of Agamemnon," as the so-called "treasury of Atreus" is here termed, was closed by an enriched bronze plaque ( $p$. 139). The Heraeum at Olympia (pp. 147, 176) is no older probably than the oldest Argive Heraeum excavated by the Americans and not mentioned by Warren. It, too, had wooden columns and marks the transition to the Doric style. The cella of the early temples is unlike the megaron ( $p .147$ ) at Tiryns but not unlike the Thessalian megaron. The crepidoma has usually three steps, of which the topmost is the stylobate, sometimes, especially in Sicily, more, but not two ( $p$. 161). Even the so-called Theseum has three steps, not two, as some of the older books say. P. 235, Powell's plan of the temple at Corinth $(A . J . A . \mathrm{IX}, 1905$, pp. 44f) supersedes Dörpfeld's which is reproduced in figure 72. P. 261, read Amasis for Amosis. P. 266, figure 84 from Furtwängler and Urlichs, Greek and Roman Sculpture (English edition by Taylor, 1914) is attributed to Furtwängler's Mastarpieces of Greek and 
Roman Sculpture. P. 282, figure 90, the name of the excavator of Miletus is Wiegand, not Weigand. $P$. 284, the temple of Cybele at Sardis should be the temple of Artemis, and figure 91 is upside down. $P$. 304, long before the Romans Pericles and later Antiochus had reared a temple on the foundations of the Olympieum. P. 305, G. F. Hill should be B. H. Hill, the director of the American School in Athens. P. 307, and p. 301, with reference to the plan of the acropolis at Athens, the new location for the monument of Nicias discovered by Dinsmoor ( $A . J . A$. XIV, 1910, pp. 459f) should be given. P. 309, the Erechtheum is wrongly said to have been used as a harem and the Parthenon to have been destroyed in 1686. The date was September 26, 1687. P. 310, the horses of Poseidon are given to Athena. P. 311, the west wall of the Erechtheum was not overthrown by a bombardment between 1824 and 1832 , but by a windstorm of 1852 , which also threw down one of the columns of the Olympieum. P. 323, the rear chamber in the Parthenon was called Parthenon because it was the chamber of the Virgin Goddess, Athena Parthenos, not because it was a virgin's chamber (cf. Arch. Anz. 1894, p. 122). P. 333, the acroteria of the Parthenon have been reconstructed from fragments, (cf. the British Museum publication of the Sculptures of the Parthenon by A. H. Smith). Pp. 342, 343, J. R. Wheeler becomes G. R. Wheeler.

There are also many theories with which not all students of Greek architecture would agree. The Doric column is supposed to have a stone origin but the Ionic column a wooden prototype; and the statements about the origin of the Doric entablature do not take into account the different articles on the subject, such as Holland's in $A . J . A$. XXI, 1917, pp. 1.17f. It would have been well to cite some of the books on the origin of the Doric and Ionic columns, such as Puchstein, Die Ionische Säule, and Lichtenberg Die Ionische Säule, both published in 1907 but with opposite theories. On the whole, however, the book is a very good and readable account of the main characteristics of architecture down to $400 \mathrm{~B}$. C.

David M. Robinson. 